\title{
THE EVALUATION OF POSSIBILITY OF NORMAL OPERATION OF CABLES BASED ON TWISTED PAIRS WITH PVC JACKET UNDER THE CONDITIONS OF HIGH HUMIDITY AND TEMPERATURE
}

Introduction. Development of cables for structured cabling systems based on twisted pairs for shipbuilding is carried out in two main directions: increasing the fire safety of cables and increasing the long-term permissible operating temperature by using new, more heat-resistant, electrical insulating materials. Purpose. Substantiation of the possibility of unshielded cables on the basis of unshielded twisted pairs with thermoplastic polyethylene insulation in PVC protective jacket in conditions of high humidity and high operating temperatures on the basis of the results of accelerated aging. Methodology. The cycle of aging under conditions of increased humidity is performed for 336 hours. Then the sample was under natural drying conditions for 1440 hours. Thermal aging in a thermostat at $90{ }^{\circ} \mathrm{C}$ was carried out in two stages: first-for 206 hours, the second-for 260 hours. In the initial state and after accelerated aging, measurements of the capacitance and tangent of the dielectric loss angle of all the insulating gaps at frequencies of $100 \mathrm{~Hz}, 1$ and $10 \mathrm{kHz}$ were performed. Results. According to the results of accelerated aging under conditions of high humidity and temperature, it is established that the design of an unshielded cable based on unshielded twisted pairs with thermoplastic polyethylene insulation in a protective coating based on PVC-plastic is resistant to external influencing factors. Practical value. The prolonged holding at temperature of $90{ }^{\circ} \mathrm{C}$ is equivalent to operation at temperature of $40{ }^{\circ} \mathrm{C}$ for 6.8 years. At higher operating temperatures, the lifetime of the cable is significantly reduced. References 5, tables 1 , figures 5 .

Key words: cables based on twisted pairs for shipbuilding, accelerated aging, hygroscopic moistening, thermal aging, partial capacitance, tangent of the dielectric loss angle, service life.

Представлены результаты ускоренного старения в условиях повышенной влаэжности и температуры образца неэкранированного кабеля на основе витых пар с полиэтиленовой термопластичной изоляцией в зацитной оболочке на основе поливинилхлоридного пластиката. Оценка устойчивости кабеля к действию внешних воздействующих факторов выполнена по частичным емкостям и тангенсу угла диэлектрических потерь изоляционных промежутков между жилами. Конструктивная особенность кабеля приводит к группированию частичных емкостей в четыре характерные области. Установлена динамика изменений диэлектрических параметров в процессе гигроскопического увлажннения, естественной сушки и теплового старения при температуре $90{ }^{\circ}$ С образца кабеля. Определены коэффициенты парной корреляции межсу диэлектрическими параметрами в исходном состоянии и после внешних воздействующих факторов. Показано, что конструкция кабеля устойчива к действию повышенной влажности и температуры. Библ. 5 , табл. 1 , рис. 5 .

Ключевые слова: кабели на основе витых пар для судостроения, ускоренное старение, гигроскопическое увлажнение, тепловое старение, частичные емкости, тангенс угла диэлектрических потерь, срок службы.

Introduction. The development of the shipbuilding infrastructure includes the presence of modern branched structured control systems with high-speed data transmission.

Shipboard cables have higher requirements for electrical, installation characteristics, resistance to external factors (temperature, humidity, vibration, solar radiation, etc.) than to cables for general industrial use. Cables for the industrial interface must meet the safety criteria and technical requirements, primarily fire and explosion safety $[1,2]$.

It should be noted that about $60-70 \%$ of the total number of electrical cables on the ships are cables of control, signaling and communication systems. Development of cables for structured cabling systems based on twisted pairs for shipbuilding is carried out in two main directions: increasing the fire safety of cables and increasing the long-term permissible operating temperature by using new, more heat-resistant, electrical insulating materials. It is shown in [3] that cables of general industrial use on the basis of twisted pairs of category $5 \mathrm{e}$ can operate under conditions of increased radiation situation.
The goal of the paper is substantiation of the possibility of operation in conditions of high humidity and high operating temperatures of unshielded cable based on unshielded twisted pairs with thermoplastic polyethylene insulation in a protective polyvinylchloride (PVC) jacket according to the results of accelerated aging.

Characteristic areas of partial capacitances of insulating gaps. The evaluation of the cable's resistance to the action of external factors acting on partial capacitances and the tangent of the dielectric loss angle of the insulation gaps between the wires. Shrinkage of insulation in the process of thermal aging or swelling during prolonged hygroscopic moistening leads to a change in the characteristics of the insulation gaps of the cable.

For cables based on twisted pairs, a random orientation of the pairs is characteristic. The twisting steps of unshielded twisted pair (UTP) are different to provide the required noise immunity: as a result, the distances between the wires are averaged, which causes the number of groups of partial capacitances to decrease. For example, in a 4-pair UTP-based cable (Fig. 1, 2), the 
distance between wires 1 and 3 is on the average the same as between wire 1 and any other $-4,5,6,7$ or 8 . As a result, all partial capacity between the 8 -th wires (and there are as many such capacitances as the sides of the 8 -gon, i.e. $\left.N=\frac{n(n-1)}{2}=\frac{8(8-1)}{2}=28\right)$ are grouped in only 4 regions - Fig. 3 .

The first area is the capacitance between the contacting wires of the same pair $(\boldsymbol{i}-\boldsymbol{j}$ - intervals: $1-2,3$ $-4,5-6,7-8$, Fig. 1$)$; the second one is the capacitance between the wires of the contacting pairs (i-k - intervals, for example: $1-7,1-8,2-7,2-8$, Fig. 1$)$; the third one is the capacitance between the wires of noncontiguous pairs $(\boldsymbol{i}-\boldsymbol{l}$ - intervals: $1-5,1-6,2-5,2-6$, etc., Fig. 1). The fourth group can be measured according to the "wire - versus all others» scheme $(\boldsymbol{i}-\boldsymbol{s}$ - area of insulation of the wires, for example, $1-2,3,4,5,6,7,8$, Fig. 1).

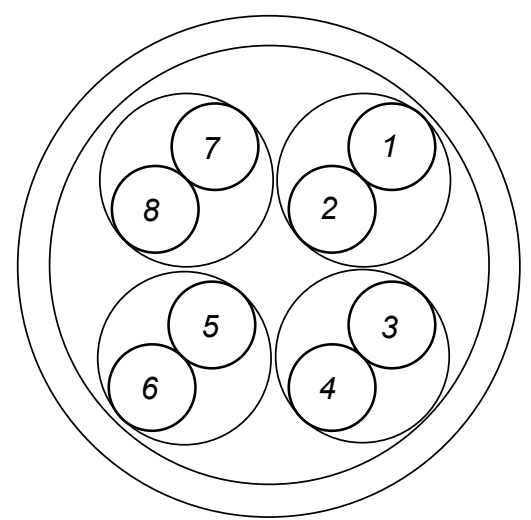

Fig. 1. Scheme of an unshielded twisted-pair cable (UTP): 4 twisted pairs, with different twisting steps (the case of the same orientation of twisted pairs, possible on separate sections of the cable)

The regulatory characteristics of the insulation gaps are determined on the basis of the calculation of the electrostatic field. Fig. 2 shows the lines of the electric field with different schemes for feeding the potential to the conductors: to the second wire of the first pair (Fig. $2, a)$; to the second wire of the first and eighth wire of the fourth pair (Fig. 2,b); to the second wire of the first, the eighth wire of the fourth and third wire of the second pair (Fig. 2,c); to the second wire of the first, the eighth wire of the fourth, the third wire, the second and fifth wire of the third pair (Fig. 2,d); to the second wire of the fourth pair (Fig. 2,e), respectively. Based on the calculation of the electrostatic field, the linear capacitances $(C)$ and the fraction of the stored energy $(\eta)$ [4] of the potential wires are determined with respect to the total energy stored in the cable (Fig. 3): $C=53.0 \mathrm{pF} / \mathrm{m} ; \eta=0.506-$ for one internal (Fig. 2,a); $\mathrm{C}=37.7 \mathrm{pF} / \mathrm{m} ; \eta=0.473$ - for one external (Fig. 2,e); $\mathrm{C}=101.9 \mathrm{pF} / \mathrm{m} ; \eta=0.524$ - for two internal (Fig. 2,b); $\mathrm{C}=114.2 \mathrm{pF} / \mathrm{m} ; \eta=0.571-$ for four internal (Fig. 2,d); $\mathrm{C}=6.214 \mathrm{pF} / \mathrm{m} ; \eta=0.0085$ - for eight wires together. The share of energy stored in the solid insulation of the wires is about $50 \%$. Consequently, the dielectric losses in the insulating gaps (such as «solid phase-air») should also be about $50 \%$ of the losses in the solid dielectric itself.

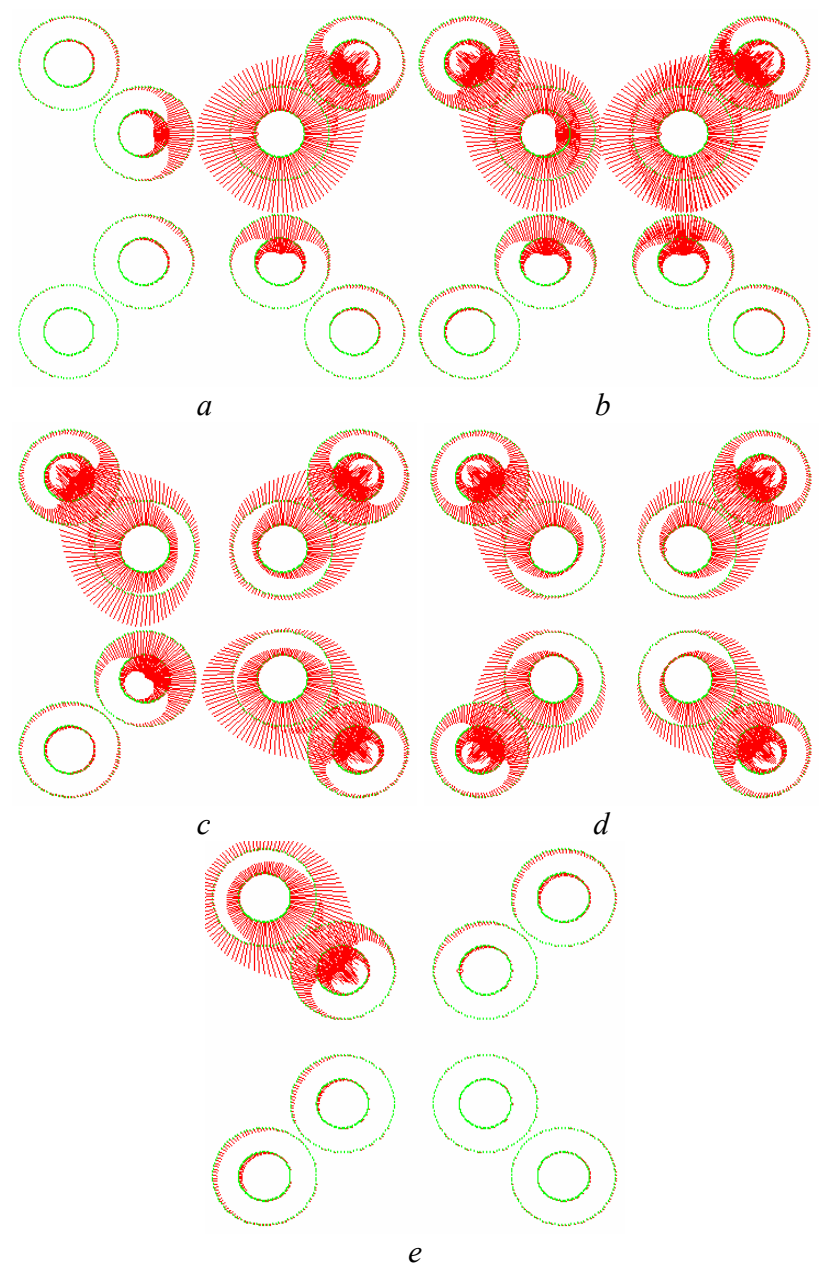

Fig. 2. Pictures of electric field lines in the cross-section of UTP-cable with different orientation of pairs at different schemes of potential supply to the conductors

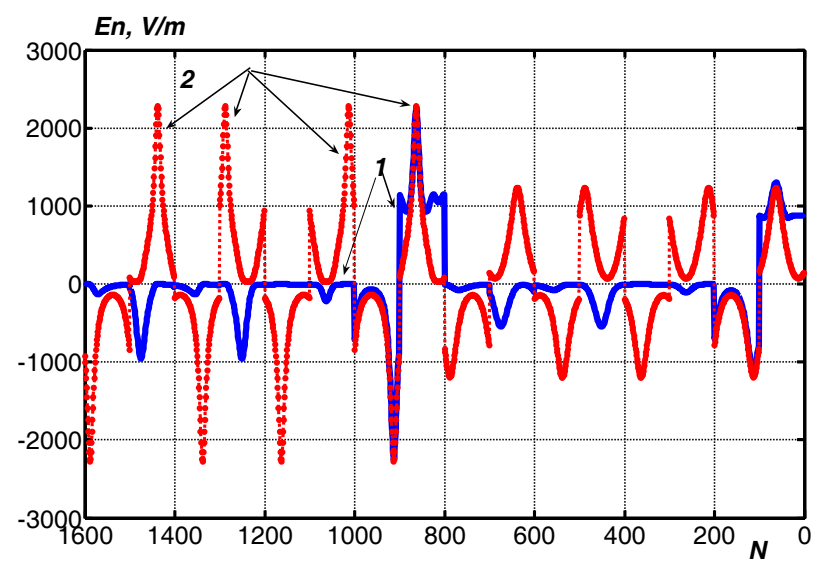

Fig. 3. The distribution of the electric field strength when the potential is to applied one (curve 1) and four (curve 2) internal wires of twisted pairs in the UTP-cable (the number of main nodes is $N=2500$, that is, the order of the system of linear algebraic equations)

Dynamics of changes in the parameters of insulation gaps as a result of accelerated aging. Experimental studies were performed on a UTP-cable of category $5 \mathrm{e}$ sample of length of $1.8 \mathrm{~m}$. Their purpose is to check the stability of the cable of the basic design with thermoplastic solid polyethylene insulation in a protective shell based on polyvinyl chloride plastic to the effect of high 
humidity and temperature. The cycle of aging under conditions of increased $100 \%$ humidity in a desiccator (hygroscopic moistening of the sample-through unsealed ends) was performed for 336 hours. Then the sample was under natural drying conditions for 1440 hours. The thermal aging in a thermostat at $90{ }^{\circ} \mathrm{C}$ was carried out in two stages: the first - for 206 hours, the second - for 260 hours.

In the initial state and after accelerated aging, measurements of the capacitance and tangent of the dielectric loss angle of all the insulating gaps at frequencies of $100 \mathrm{~Hz}, 1$ and $10 \mathrm{kHz}$ were performed.

Fig. 4, $a$ shows the parameters of the insulation gaps of a UTP-cable of category 5e sample in the initial state. For the «wire-wire of the same pair» intervals, the lowest levels of $\operatorname{tg} \delta$ are observed, with $\operatorname{tg} \delta$ falling with increasing frequency.
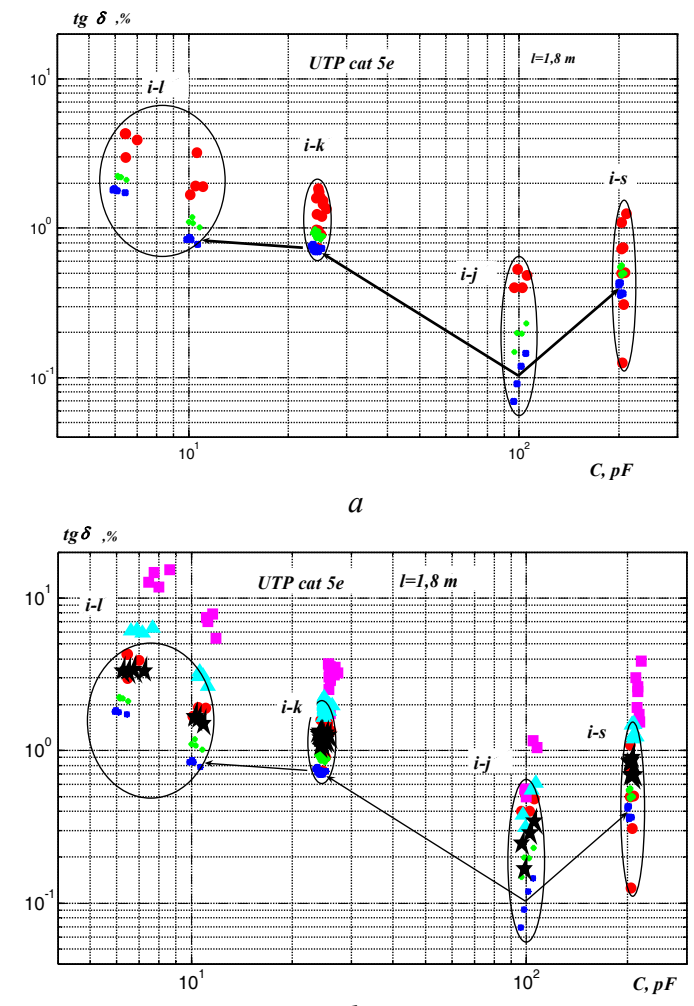

$b$

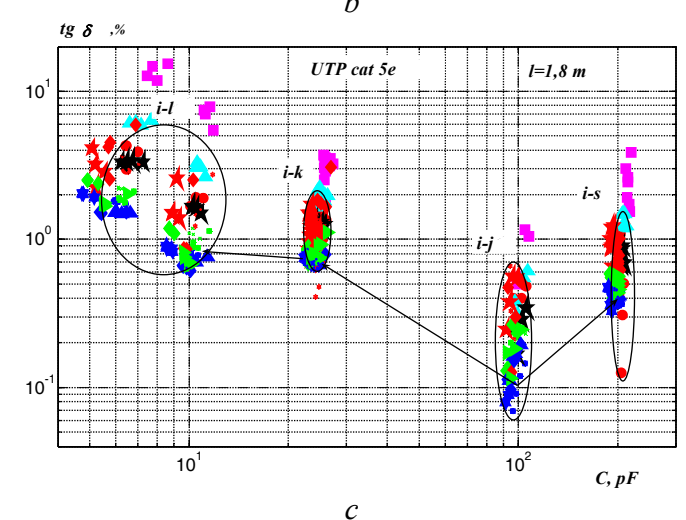

$c$

Fig. 4. Dynamics of changes in partial capacitances and tangent of the dielectric loss angle in the process of accelerated aging under conditions of high humidity and temperature

External influence - hygroscopic moistening - leads to a strong change in the parameters of only some regions
- Fig. 4,b (the experimental points lie outside the selected regions). This is a consequence of the appearance of moisture in the capillaries formed by contacting insulated cores [5]. Fig. 5, $b$ shows the parameters of the insulating gaps in the initial state and after a two-week exposure (336 hours) in the desiccator. The capacitances of the gaps have increased little, but $\operatorname{tg} \delta$ has grown significantly more, and to a greater extent for wires distant from each other (the region of small partial capacitances, the left part of Fig. 4,b). After extraction from the desiccator and natural drying for two months (1440 hours), a decrease in $\operatorname{tg} \delta$ is observed due to the removal of moisture from the surface of the isolated wires and a decrease in partial capacities due to swelling of the insulation (diffusion of moisture into the thickness of the insulation).

As a result of thermal aging at temperature of $90{ }^{\circ} \mathrm{C}$, the decrease in $\operatorname{tg} \delta$ continues due to the removal of moisture from the insulation layer and the growth of partial capacities due to shrinkage of insulation. Drying the cable at a temperature of $90{ }^{\circ} \mathrm{C}$ for 260 hours resulted in an almost complete restoration of the electrical characteristics of all its insulating gaps (see Fig. 4,c). In this case, the PVC jacket slightly changed in color, lost its shine, but retained its elasticity.

There is a positive correlation, both for partial capacitance and for the tangent of the dielectric loss angle (Table 1).

Table 1

Coefficients of mutual pair correlation between the capacitance in the initial state and the capacity after accelerated aging $\left(r_{\mathrm{C}}\right)$, between the tangent of the dielectric loss angle in the initial state and after accelerated aging $\left(r_{\mathrm{tg} \delta}\right)$

\begin{tabular}{|c|c|c|c|c|}
\hline \multirow{3}{*}{ 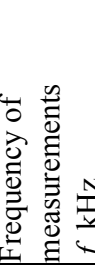 } & \multicolumn{4}{|c|}{ Conditions of accelerated aging } \\
\hline & $\begin{array}{l}336 \text { hours } \\
\text { under } \\
\text { conditions } \\
\text { of } 100 \% \\
\text { humidity } \\
\end{array}$ & $\begin{array}{l}1440 \text { hours } \\
\text { At normal } \\
\text { conditions }\end{array}$ & $\begin{array}{l}206 \text { hours of } \\
\text { heat aging at } \\
\text { temperature } \\
90{ }^{\circ} \mathrm{C}\end{array}$ & $\begin{array}{l}456 \text { hours of } \\
\text { heat aging at } \\
\text { temperature } \\
90^{\circ} \mathrm{C}\end{array}$ \\
\hline & & & $r_{C}$ & \\
\hline \multirow{3}{*}{0.1} & 0.9998 & 0.9998 & 0.9999 & 0.9998 \\
\hline & \multicolumn{4}{|c|}{$r_{\mathrm{tg} \delta}$} \\
\hline & 0.9001 & 0.8176 & 0.8578 & 0.7876 \\
\hline \multirow{4}{*}{1} & \multicolumn{4}{|c|}{$r_{\mathrm{C}}$} \\
\hline & 1.0000 & 0.9999 & 0.9999 & 0.9999 \\
\hline & \multicolumn{4}{|c|}{$r_{\operatorname{tg} \delta}$} \\
\hline & 0.9810 & 0.9909 & 0.9876 & 0.9622 \\
\hline \multirow{4}{*}{10} & \multicolumn{4}{|c|}{$r_{\mathrm{C}}$} \\
\hline & 1.0000 & 1.0000 & 0.9999 & 0.9999 \\
\hline & \multicolumn{4}{|c|}{$r_{\mathrm{tg} \delta}$} \\
\hline & 0.9111 & 0.9966 & 0.9942 & 0,9904 \\
\hline
\end{tabular}

The values of the selective linear paired coefficient of K. Pierson correlation $r$ are large for partial capacitances and, in practice, vary only slightly at different frequencies (see Table 1). For the tangent of the dielectric loss angle, the more pronounced frequency dependence $r_{\operatorname{tg} \delta}$ is characteristic: the pair correlation coefficient has large values at the frequency $1 \mathrm{kHz}$ and 10 $\mathrm{kHz}$, which is associated with both the polarization processes and the electrical conductivity in the insulation. 
As an adequate lifetime of the cable sample, the estimated service life, obtained on the basis of parameters of the accelerated aging regime, adequate to the aging of the cables under operating conditions (Fig. 5) is taken. The normal operation time of the cable is 1.14 years and 6.8 years at an operating temperature of $60^{\circ} \mathrm{C}$ and $40{ }^{\circ} \mathrm{C}$, respectively.

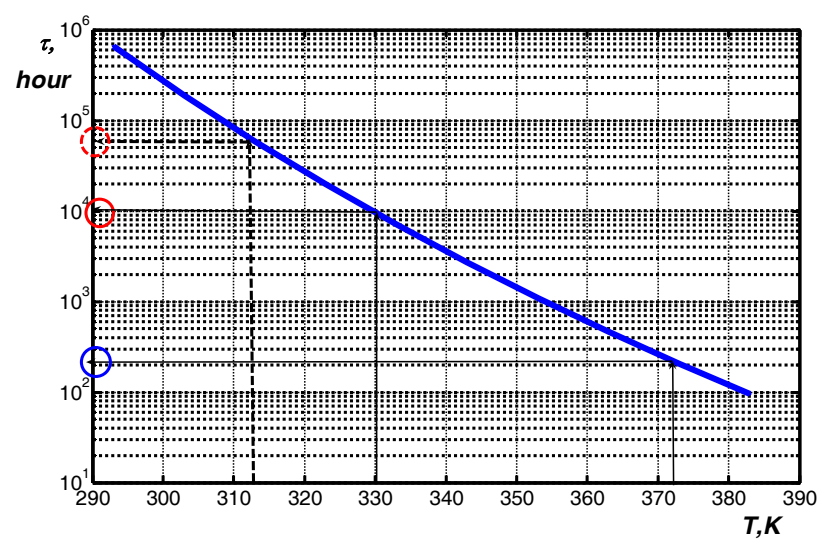

Fig. 5. To assess the life of the cable under normal operating conditions

Conclusions. The results of accelerated aging of unshielded cable based on unshielded twisted pairs with thermoplastic polyethylene insulation in a protective jacket based on PVC-plastic material in conditions of high humidity and temperature show that the design is resistant to external influencing factors. The prolonged holding at $90{ }^{\circ} \mathrm{C}$ is equivalent to operation at temperature of $40{ }^{\circ} \mathrm{C}$ for 6.8 years. At higher operating temperatures, the lifetime of the cable is significantly reduced.

\section{REFERENCES}

1. IEC 60092-359:2014, Electrical Installations In Ships - Part 359: Sheathing Materials For Shipboard Power And Telecommunication Cables By IEC TC/SC 18A. 50 p.

2. IEC 60332-1-2:2004, Tests on electric cables under fire conditions - Part 1: Test on a single vertical insulated wire or cable.

3. Bezprozvannych G.V., Naboka B.G., Morozova E.V. Radiating resistance of common commercial cables of internal laying. Electrical engineering \& electromechanics, 2006, no.3, pp. 82-86. doi: 10.20998/2074-272X.2006.3.16. (Rus).

4. Bezprozvannych A.V., Naboka B.G., Moskvitin E.S. Examination of the three-phase insulation of cables in a metal shell. Electricity, 2010, no.1, pp. 48-54. (Rus).

5. Bezprozvannych A.V. The electrical scanning of the transverse structure by multicore cables by the method of cumulative measurements. Tekhnichna elektrodynamika, 2008, no.3, pp. 30-36. (Rus).

Received 25.08.2017

G.V. Bezprozvannych ${ }^{1}$, Doctor of Technical Science, Professor, I.A. Mirchuk ${ }^{2}$, Postgraduate Student,

${ }^{1}$ National Technical University «Kharkiv Polytechnic Institute», 2, Kyrpychova Str., Kharkiv, 61002, Ukraine, phone +380 577076010 ,

e-mail: bezprozvannych@kpi.kharkov.ua

${ }^{2}$ Private Joint Stock Company «Ukraine Scientific-Research Institute of Cable Industry»,

2-P, Promychlennaya Str., Berdyansk, Zaporozhye Region,

71101, Ukraine,

phone +380668288554,

e-mail: garik710@ukr.net

How to cite this article:

Bezprozvannych G.V., Mirchuk I.A. The evaluation of possibility of normal operation of cables based on twisted pairs with PVC jacket under the conditions of high humidity and temperature. Electrical engineering \& electromechanics, 2017, no.5, pp. 51-54. doi: 10.20998/2074-272X.2017.5.08. 